\title{
ユーカリチップの屋外貯蔵 $(\mathrm{OC} \mathrm{S})$ による劣化
}

$\begin{array}{ll}\text { 紙谷 } & \text { 清* } \\ \text { 依 } & \text { 田* }\end{array}$

\section{1.はじめに}

日本は人口の割に森林資源がそしく、さらに自 然保護といら立場から伐採を制限されているの で、日本の紙令業は紙の安定供給といら使命の ために原木を海外に求めている。

昭和49年に紙の需要が大幅に減少したが、輸入 チップは長期契約のため翰入量を堿少させるには 困難があった。その結果、輸入チップの在庫量は 大幅に増加してしまった。

当社も昭和 48 年より、オーストラリアのタスア ニア島からユーカリチップを輸入し始め、一時は 6か月の在庫をもつことになった。このチップの 一部が劣化したので調査研究を実施した。本報は 我々の研究の一部であるが、同テーマの研究担当 者への参考資料として役立てば幸いである。

（注）１．本報に揭载した「パルプ収率」はすべて実娩 室のオートクレーブで丞解したテスト結果であ る。

2. 劣化の指標としては $1 \%$ ルカリ可溶分がも っとも精度が高いのでこれを採用している。

\section{2. o C S (Outside Chip Storage) における チップの少化状況}

，当社八戸工場はユーカリチップ用に巾90m、長 さ320m のコンクリート製のOCS設備をもって いる。このOC Sを建設するにあたり、ニーカリ チップの小テストパイルを構築して劣化の是非を 検討した経験があり、この結果によると、ユーカ リチップは1年経過後でも、容積重、パルプ収 率、パルプ強度は变化せず、劣化現象は見られな かった。

ところが、在積量が多くなってきたので入船每

*三蔆製紬侏八戸工埸
のチップを順に上に積重ねなければならず、OC Sは25mの高さに達し最下周のチップはすでに 年以上を経過する結果となってしまっだ。したが って、変色チップが発見されたのを機会として少 化調查が実施された。

少化部分はOC S の中央部に限られ、水平方向 の外周部、垂直方向の頂上部および底部には劣化 チップは発見できなかった。

少化部分（底部から 5〜20mにわたる部分）垂 直断面を 5 層に均等分割したとき、特に頂上から 第二層の劣化が著しく、パルプ.収率は35.0〜37.4 $\%$ （健全チップでは50.0\%）を記録した。この部 分のチップは褐色を゙呈し、酸臭が感知され、同時 に大量の菌が発見された。第一、三、四層のパル プ収率は45.0〜 48.3\%であり、底に近い第五層は 49.1\%であった。このときのパイルの温度は測定 していないが、外気温とほぼ等しいと思われた。 ところが、OC S の他の部分では文献に記されて いるよらに50〜 $60^{\circ} \mathrm{C}$ の高温を保っている部分も発 見された。この部分は、前述の劣化部分から離れ た所で発見されたが、やはりパイルの中央部であ った。当初、パイル頂上部では水蒸気の発生が観 察された。頂上部から下に掘り進むにしたがって 温度は高く、平均して約 $60^{\circ} \mathrm{C}$ であったが、最高 83 ${ }^{\circ} \mathrm{C}$ に達する部分も一部発見された。同時に、ダス 卜率（4.8 m 以下）と.7\%アルカリ可溶分好下層 部に移行するほど、増加傾向を示し、“頂上付近 (高さ $20 \mathrm{~m}$ ) ではダスト率 6.0 7.1\%（健全于 ップでは 4.0\% 以下). $1 \%$ アルカリ可溶分24.5〜 28.3\%（健全チップでは24.0〜26.0\%）が、高さ 15〜16m付近ではダスト率 8.8〜20.9\%、.1\%ア ルカリ可溶分29.7〜 41.6\%にも達した。パルプ収 辛は平均39.0\%であった。この部分のチップは1 
年以上経過していると推定される。やはり、チッ プは褐色を呈し、酸臭が認められた。菌も所タコ ロニーとして発見された。

以上、OC Sに括けるチップの少化状況および 種々の観察結果が、パイル温度、菌の繁殖、チ ップの劣化の三者は密接に関係していると考兄ら れる。少化部分で温度が低い部分があったのは、 技そらくパイルの断層を露出した後、温度が低下 したのであろう。

\section{3. 劣化チップのパルプ化の問題点}

今回、我々が入手し得た劣化の最も進んだチッ プと、健全チップを実験室に扎いて蒸解テストし た結果は表 1 通りである。

表 1健全チップと劣化チップの特性

\begin{tabular}{|c|c|c|c|c|c|c|}
\hline \multirow[b]{2}{*}{ チップ } & \multirow{2}{*}{ 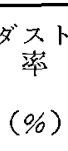 } & \multirow{2}{*}{$\begin{array}{l}\text { 容積重 } \\
\left(\mathrm{kg} / \mathrm{m}^{3}\right.\end{array}$} & \multirow{2}{*}{$\mid \begin{array}{l}\text { 次プ } \\
\text { 仅 率 } \\
(\mathrm{AD} \%)\end{array}$} & \multirow{2}{*}{$\begin{array}{l}\text { カッパ } \\
-\quad \text { 価 } \\
\end{array}$} & \multicolumn{2}{|c|}{ 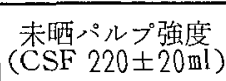 } \\
\hline & & & & & 比引致度 & 比破裂度 \\
\hline $\begin{array}{l}\text { 健 全 } \\
\text { チップ }\end{array}$ & 4.0 & 550 & 50.0 & 17.7 & 110 & 5.4 \\
\hline $\begin{array}{ll}\text { 少 } & \text { 化 } \\
\text { チップ }\end{array}$ & 20.9 & 490 & 24.3 & 37.5 & 48 & 3.1 \\
\hline
\end{tabular}

チップの劣化による影響は、

1) 劣化チップは重量が減少する。

この重量減少は、容積重 $\left(\mathrm{kg} / \mathrm{m}^{3}\right)$ を测定す ることにより推定しうる。この場合の重星減少 は

$$
\{(550-490) / 550)\} \times 100=10.9(\%)
$$

となる。

2）パルプ収率が減少する。

健全チップのクラフトパルプ収率は50\%であ るが、劣化チップでは約24\%であった。前述の 重量減少とあおせると、同一重量のチップから 得られるパルプの重量は、劣化チップのパルプ は健全チップのパルプの44.5\%である。

3）劣化チップは蒸解しにくい。

アルカリ添加率 $18 \%$ 、保持温度 $172^{\circ} \mathrm{C}$ 、保 持時間 50分、液比 4 でクラフト蒸解すると、 カッパー価は健全チップで17.7、劣化チップは 37.5で、劣化チップは蒸解しにくい。このた め、劣化テップを煮るためにはアルカリ量を增
やさねばならない。

4）劣化チップのパルプは強度が低い。

表1に示すごとく強度が低下している。これ は、パルプのセルロース重合度が低下している ことからも理解できる。

5）劣化チップはダスト量が多い。

劣化すると、4.8mm 目の簎を通過するダスト 量は約 5 倍に增加する。蒸解工程では昨温する ために間接加熱を行なっているが、ダストの增 加によってそのラインにあるストレーナーの目 が詰まり、蒸解温度を上げるのに時間がかかり 生䐂性を低下させる。特に、カミヤ式の連続ダ イジェスターではストレーナーの目詰まりが生 じると停機しなければならないので、一般にダ ストは除去して使用されている。

さらに、OC Sから蒸解鉒までは風送管でチ ップを送っているので劣化チップは䂗けやす く、ダストはこの工程でさらに增加している。 以上のごとく劣化チップは薬品の使用量が多 く、収率为悪く、生砤性も低いが、当社では、少 化チップを一定量少量ずつ健全チップの中に添加 する方法と、漂白工程の対策によって、パルプ品 質を低下させることなしに、少化チップの処理を 完了した。

\section{4. チップ劣化の原因とメカニズム}

少化チップを発見した当初、同時に菌も大量に 発見されたので、チップ劣化の原因は菌の腐朽作 用によるものと推定されたが、その後のパイル観 察結果、実験結果、文献からの情報から、菌の窇 朽作用より、むしろパイルの温度上昇が化学反応 （酸化反応、酸加水分解反応）を促進することによ る䓡劣化であることが明らかになった。しかし、 $60^{\circ} \mathrm{C}$ のよな高温でる死隇せず木材を简朽させる 菌も発見されているので、菌少化を否定するもの ではない。扣そらく、パイル内では菌少化と熱劣 化の両者が作用しているのであるらが、熱劣化の 比重が高いことを述べているにすぎない。

したがって、チップの少化はパイルの温度上䄯 と密接な関係があり、パイル温度をコントロール することがチップの少化防止に最大の效果をもた らすことは自明である。 


\section{1パイルの温度上昇の原因とメカニズム}

\subsection{1 熱発生源}

熱発生源としては、次の 5 因子が䓔光られて い。

1，生きている木材柔細胞の呼吸 ${ }^{122) 33}$

2. バクテリアの生物的活動

3. 木材腐朽菌の生物的活動

4. 化学的酸化反応 ${ }^{2>}$

5. 孷水化物の酸加水分解反応 ${ }^{5>}$

4.1.2 パイル温度上曻のメカニズム

パイル温度上界のメカニズムは、前述の 5 因 子が複雑にからみ合い、競争反応的に熱を発生 させ、その熱によってさらに 5 因子の活動が活 発化し、それ以上の熱を放出するというょうに、 循環形式をとるので、パイル温度は加速的に上 昇する。（図1参照）

屯ず、パイルが權築された当初、パイル中の
豊富な酸素を利用して木材中の生細胞（放射柔 細胞）が呼吸活動を行なっている。このとき、 呼吸熟を放出するのでパイル温度が上䒜する。 パイリング後数週間で最初に温度が上昇するの は、明らかに、木材柔細胞の呼吸、バクテリア の繁殖、化学的酸化作用化上るものである ${ }^{4}$ 。 そのうちに、低温菌も活動を始好熱発生に寄与 する。このようにして、徐々にパイル内部に熱 が蓄㺓され、パイル温度が上升するにつれて、 ますをす、木材中の生細胞の呼吸、バクテリ ア、菌の生物的活動は促進される。同時に、化 学反応（化学的酸化 反応、酸加水分解 反応） も、温度上年によって反応速度が高索るこれ らの化学反応も発熱反応であるため、パイル温 度上算に寄与する。 $42^{\circ} \mathrm{C}$ 以下の温度では、生き ている木材柔細胞の呼吸が主要な熱源である が3、それ以上の温度では化学的酸化反応がそ

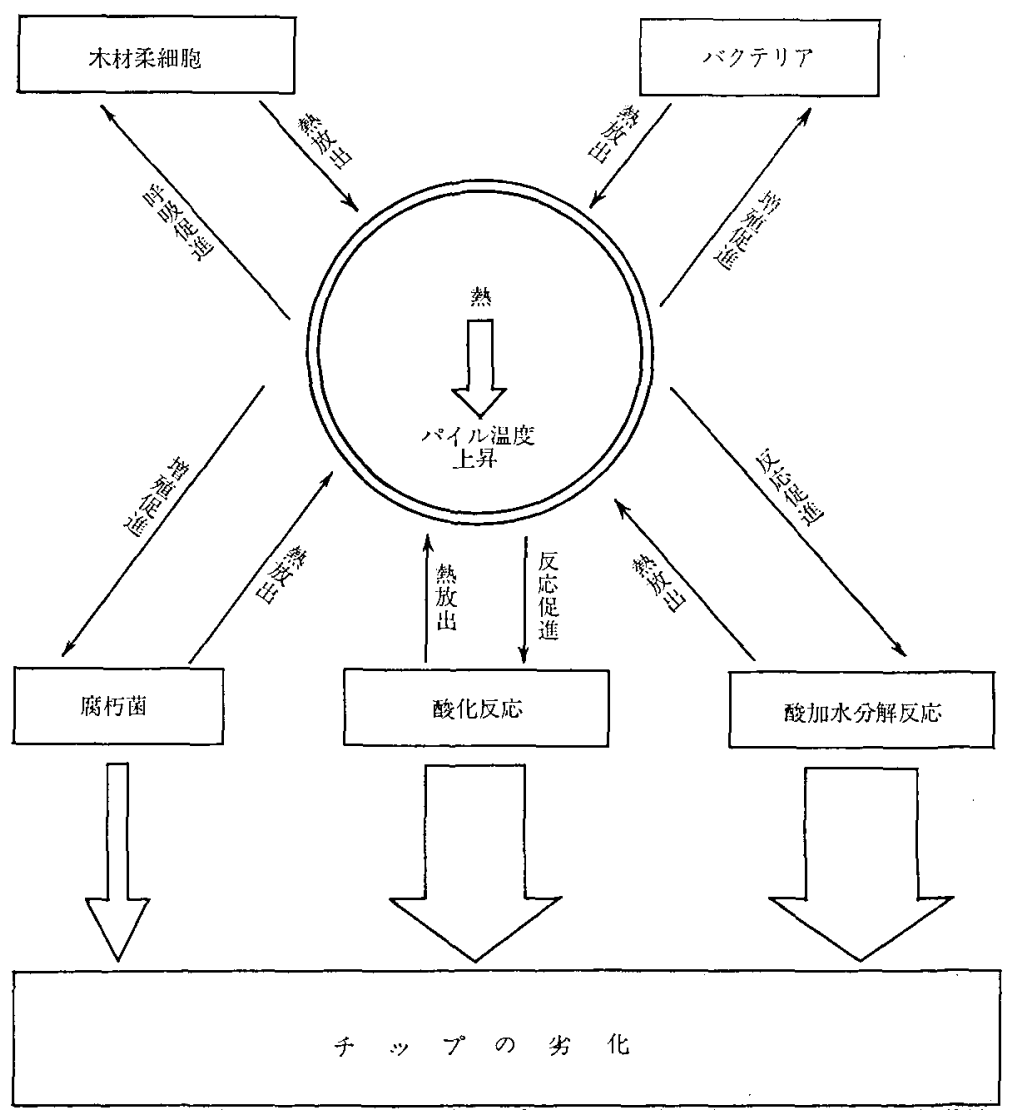

図1パイル温度上䒜とチップの劣化のメカニズム

（*矢印の太さ㤃劣化の寄与の大小を表示） 
の比重を高め、約 $45^{\circ} \mathrm{C}$ に達した後、木材柔細胞 の呼吸機能は停止し、約 $60^{\circ} \mathrm{C}$ で細胞組織は破壊 され死滅するので、約 $45^{\circ} \mathrm{C}$ 以上では熱発生に寄

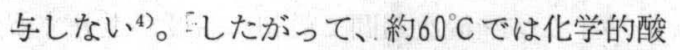
化反応が主要な熱源となる4)。また、菌やバク テリアの活動による熱量も無視できない。パイ ル温度上年の当初は低温菌、温度上年にしたが って、中温菌、高温菌へと移行し、バクテリア も同じ経過をとる。バクテリアは最初の数日間 で急速に増加する。腐朽菌と異なる点は、 $70^{\circ} \mathrm{C}$ でも生育できることである5)。

\subsection{3 煙突ドラフト効果 ${ }^{1)}$ (図 2 参照)}

木材柔細胞、菌、バクテリア（好気性）の呼 吸活動の結果、パイル中の酸素が消費され、呼 吸熱之二酸化炭素、水が放出される。熱によ。 て加熱された空気は上向きの対流を開始するの で、パイル内部の高温領域は減圧状態となる。 したがって、外気圧との差を埋めるために、新 鮮な空気がパイル周囲の下部からパイル内に流 入する。この新鮮な空気は、パイル中央部の高 温領域を通過する間に、水分、酸性蒸気、バク テリアや菌の胞子、菌系を取込み、パイル頂上 部まで運ぶ。頂上近くでガス気流は冷却され、 水蒸気は凝縮するので、頂上のチップは高水分 である。逆に、高温領域のチップは乾燥してい る。このようにして、煙突ドラフト効果はパイ ル内部に蓄積する熱を大気中に発散する効果と バクテリアや菌の繁殖を促進する効果を有す る。したがって、パイリング後数週間で加速的 に上年したパイル温度は、パイル内部で生成す る熱量と煙突ドラフト効果によって大気中に放 出される熱量とがバランスしたときの温度で落 着く。

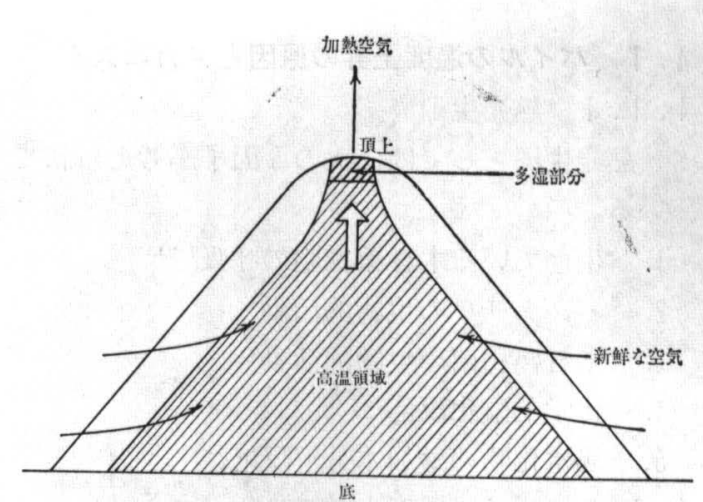

図 2 煙突ドラフト効果

\section{2 チップ劣化の原因}

チップ劣化の間接的原因は前述したパイルの温 度上昇である。直接的原因は、木材腐朽菌の作用 と化学反応（酸化反応、酸加水分解反応）であ る。両者の関係は、前者の温度上䄯が後者の作用 を促進するという点にある。

チップ劣化に及ぼす菌劣化 (木材腐朽菌による 劣化) と熱劣化 (化学反応による劣化) の寄与率 については、まだ詳細には明らかにされていない が、当社で実施した実験結果によると、 $40^{\circ} \mathrm{C}$ 以上 の温度ではチップの劣化は主に熱劣化によるもの であった。この結論はOC S での温度、パイリン グ時間、1\%アルカリ可溶分を総合した結果を支 持している。すなわち、 OC S パイル $40^{\circ} \mathrm{C}$ 以上 の温度を記録した部分に少化現象が見られ、約60 ${ }^{\circ} \mathrm{C} て ゙ は 1$ か以内で劣化してしま5。逆に $40^{\circ} \mathrm{C}$ 以 下ではほとんど劣化現象が見られない。そこで、 この結果を実験室でシミュレーションした。すな わち、殺菌処理チップと殺菌処理をしなかったチ ップを所定の温度に保っておくと、3か月経過し ても両チップ間に菌劣化による差は見られず、し かも OC S パイルのデータと同じく、 $40^{\circ} \mathrm{C}$ 以上で 劣化し、逆に $40^{\circ} \mathrm{C}$ 以下ではほとんど劣化しないと

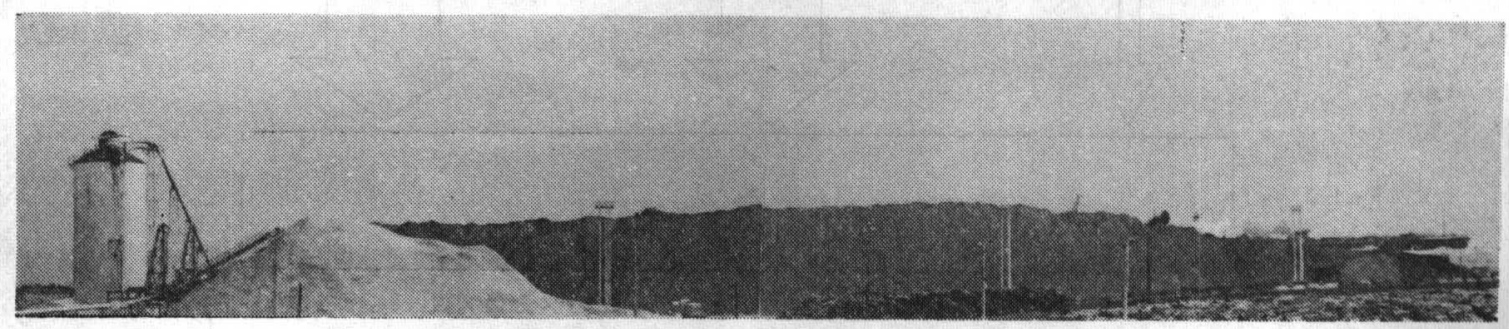

ユーカリチップの $0 \mathrm{C} \mathrm{S}$

(36) 
いら結果が得られた。以上の結果から、劣化が始 まる $40^{\circ} \mathrm{C}$ 以上の温度では、ヂップの少化の主たる ものは熱劣化によるものであると結論できる。実 際のパイルでは木材に有害な腐朽菌も存在すると 思われるので、熱劣化の他に菌少化多少化の寄与 率は小さいながらも生じているであろら。

熱劣化を生じさせる原因の主たるbのは、直接 的化学酸化反応之酸加水分解反応である。前者の 詳細についてはまだ明らかにされていないが、後 者に関しては渃干情報が得られている。木材分析 の結果によると、劣化チップのpH低下、水溶性酸 の生成量增加、炭水化物（七ルロース、へミセル ロース）の減少、特に一ミセルロースの減少、尺 ルプ收率の低下、セルロース重合度の呧下等は拉 たがいに無関係とは言い難い。したがって、上述 の結果を、Feist ら の)見解にもとづいて、次のよ らに推定してよいであるら。すなわる、パイルの 熱はチップ中の水溶性酸の生成を促進させ、この 酸が加水分解の触媒として作用し、炭水化物一 特に、へミセルロース——を可溶化するのであろ 万。

菌劣化に関しては種々の文献上の情報がある。 ところが、その大部分は中温菌（最適温度20４0 ${ }^{\circ} \mathrm{C}$ ) 一一例光ば、Basidiomycetes——炇関寸るも のであるが、高温菌（最適温度 $40 \sim 60^{\circ} \mathrm{C}$ ）に言及 しているものはごく限られていて、それも最近に なってやっと注日されてきたのが現状である。自 然のパイルは約 $60^{\circ} \mathrm{C}$ をで温度が上䒜すること、拉 よび $40^{\circ} \mathrm{C}$ 以上で少化が渚しく、 $40^{\circ} \mathrm{C}$ 以下で伍と んど劣化しないことから、当然高温菌を重視す べきである。Smith5) によれば、Chrysosporium lignorum (Nilsson が戦離、木材重量を大きく減

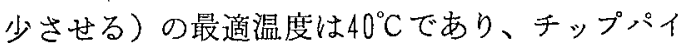
ルの外周部にその効果を発揮し、高温菌で木材㔻 朽作用を有する Ascomycetes（例えば、Talaromyces emersonii、Thermoascus aurantiacus、 Allescheria terrestrsi) が含まれていると、温度
は理想的には約 $50^{\circ} \mathrm{C}$ に上昇する。我々は高温菌の 検索は実施していないが、これらの高温菌による 劣化も認識しておくべきであるら。

\section{5. 打わりに}

我々はチップの劣化を研究するにあたり、この テーマが非常に研究しにくいテーマであるこ之を と 痛感している。その理由の第一は、チップから菌 を単離し培盖するときに、他の雑菌が繁殖するた め目的の菌種を得られないことであり、第二に、 チップの劣化に関する文献を約50通調盉した結 果、劣化については定説がないことである。我々 はこのよらな图難と闘いながら、パイルの観察か： ら始め、少化チップの特性、チップの少化の原因 とメカニズムを明らがした。

従来、菌劣化が重要視されていたが、今回の我 々の経験によると、それ以上に熱劣化が非常に重 要な問題としてクローズアップされてきている。 これを防止与る手段としては、次ル温度をコン トロールすることである。我々は、上述の見解に もとづいて種々の劣化防止法を検討中であり、す でに良好な成績をあげているものもある。

\section{引用文献}

1) A. Assarsson, I. Croon, and E. Frisk, Svensk Papperstid., 73 (16), 493 (1970).

2) E. L. Springer, G. J. Hajny, and W. C. Feist, Tappi, 53 (1), 85 (1970).

3) E. L. Springer, G. J. Hajny, and W. C. Feist, Tappi, 54 (4), 589 (1971).

4) W. C. Feist, E. L. Springer, and G. J. Hajny, Tappi, 56 (4), 148 (1973).

5) R. S. Smith, Res. Note No. R83 (1973):

6) W. C. Feist, E. L. Springer, and G. J. Hajny, Tappi, 57 (8), 112 (1974). 